\title{
Rumen bacterial community, indicators of reproduction and milk productivity at different levels of protein concentrate in the diets of dairy cows
}

\author{
Nikolay Buryakov1,*, Georgi Laptev ${ }^{2}$, Mariya Buryakova ${ }^{1}$, Larisa Ilina ${ }^{2}$, and Dmitry \\ Aleshin $^{1}$ \\ ${ }^{1}$ Federal State Budgetary Educational Institution of Higher Education «Russian State Agrarian \\ University - Moscow Timiryazev Agricultural Academy», Department of Animal Feeding, 127434, \\ Moscow, Russian Federation \\ ${ }^{2}$ Limited Liability Company «BIOTROF», 196650, Saint-Petersburg, Russian Federation
}

\begin{abstract}
The use of new sources of by-pass protein in the cow diets to optimize milk production and herd reproduction performance indicators in modern economic conditions is relevant. The article presents data on the use of a protein concentrate containing plant and animal components and its effect on the quality of the milk obtained, the state of the rumen bacterial community and reproduction indicators. The use of protein concentrate of both $1.0 \mathrm{~kg}$ and $1.5 \mathrm{~kg} / \mathrm{head} /$ day contributed to improving the quality and increasing the yield of dry matter of cow's milk by $0.17-$ $0.43 \%$. During the days in milk, with the use of protein concentrate it was observed that increase the content of Selenomonas by $1.7 \%$ and $4.1 \%$, which cleave the urea, indicates a more efficient use of nitrogen in the diet. The inclusion of protein concentrate in the composition of daily diets helps to improve reproduction indicators, reduce the duration of the service period and the number of semen doses spent.
\end{abstract}

\section{Introduction}

High-protein feed, protein concentrates and supplements make up the most expensive part of the diet, and the optimization of nitrogen metabolism leads to lower costs for milk production and an improvement in the environmental situation [3, 5-7, 14, 15]. In the feed market, the protein part of compound feeds for highly productive animals is mainly represented by products of plant origin - oil cake and meal, and animal origin - by products of processing of the dairy, meat and fish industries [3, 7, 14].

Fish meal in the diets of farm animals is currently becoming less available due to its high cost and reduced quality, and its supply is seasonal due to the limited period of fish capture [3].

\footnotetext{
*Corresponding author: kormlenieskota@gmail.com
} 
Russia meets its need for fish meal at the expense of its own production only by $12 \%$, and the rest is imported from abroad. The main producer of fishmeal on the world stage is Peru (631 thousand tons), Chile (214 thousand tons), and the leader in production is China and South Korea, where, respectively, $56 \%$ and $42 \%$ of the total production is concentrated. Recently, there has been a stagnation in the production of fish meal, which is the lowest level in the last 40 years $[3,13,14]$.

Vegetable sources of protein (legumes, oil crop cakes and meal) are rich sources of lipids and energy, but they are significantly inferior to animal feed in terms of the content of non-cleavable protein $[3,6,12,13,15]$.

\section{Materials and Methods}

Experimental studies were carried out in the agricultural complex IAPC "Plemzavod "Maysky" of the Vologda region. The object of the study was Ayrshire cows with a milk yield of more than $8000 \mathrm{~kg}$ of milk per year. The animals were divided into 3 experimental groups of 15 animals each.

During the experiment, the animals were kept in the same conditions of housing and feeding, were clinically healthy, and constant management conditions were maintained operators, similar batches of feed, frequency of milking and staff working hours. The animals on the farm were kept in tie-up conditions. Feed was provided to animals 3 times per day, milking - three times, according to the daily routine adopted in the farm.

The control group cows received the main diet used in the farm, where the nutrient content was balanced, taking into account the needs of highly productive cows in all nutrients and met the detailed recommendations for dairy cattle feeding (VIZh, 2016). The main diet during the lactation period consisted of $(\mathrm{kg})$ : hay of various grasses -0.5 , corn silage -7 , haylage of grasses -7 , barley grain haylage -12 , compound feed -11 , bypass fat "Nutracor" - 0.3, monocalcium phosphate -0.13 , table salt -0.12 .

Protein feed with a low content of non-cleavable protein. In the compound feed of the 2nd and 3rd experimental groups, the protein concentrate "Agro-Matic" was introduced with a decrease in other vegetable protein concentrated feeds. In the experimental groups with protein concentrate, the level of metabolic energy in the diets of experimental animals was at the same level $[2,8,9]$.

To study the bacterial community of the rumen at the $3^{\text {rd }}$ month of lactation, the rumen fluid was extracted according to the method of G.Yu. Laptev (2016). The samples were examined in the laboratory of "Biotrof" LLC using the T-RFLP analysis method [4].

For cheese production, an important role belongs to the quality of milk in the production process, it must meet the GOST and safety requirements. Thus, one of the milk quality criteria is its suitability for further processing [1, 11, 13]. Similarly, the qualitative composition of milk is determined by genetic factors (type, breed, line) and at the same time depends on paratypical factors: age, lactation stage, type of feeding, season and climatic conditions $[1,2,9,10]$.

\section{Results and Discussion}

To make cheese, milk with a protein content of at least $3.1 \%$, fat - more than $3.64 \%$ with a calcium content of $125 \mathrm{mg} \%$, solid-not-fat (NFMS, nonfat milk solids) are necessary, the ratio of protein and NFMS - 0.35:0.45, fat and protein - 1.1-1.25. With a decrease in $\mathrm{pH}$, rennet coagulation of milk proteins proceeds faster and as a result, a denser clot is obtained. The density of milk for cheese should be $1027 \mathrm{~kg} / \mathrm{cm}^{3}$, the titrated acidity $-16-18^{\circ} \mathrm{T}$. 
The study of feeding cows with protein concentrate on the physical and chemical parameters of milk makes it possible to assess its suitability for further industrial processing [11] (Table 1).

Table 1. Chemical composition of milk of experimental cows.

\begin{tabular}{|c|c|c|c|}
\hline \multirow{3}{*}{ Indicator } & \multicolumn{3}{|c|}{ Group } \\
\hline & \multirow{2}{*}{$1^{\text {st }}$ control } & \multicolumn{2}{|c|}{ experimental } \\
\hline & & $2^{\text {nd }}$ & $3^{\text {rd }}$ \\
\hline Density, $\mathrm{kg} / \mathrm{m}^{3}$ & 1028.7 & 1029.3 & 1031.1 \\
\hline Milk energy, $\mathrm{kJ} / \mathrm{kg}$ & 3080.31 & 3157.41 & 3179.51 \\
\hline $\begin{array}{l}\text { Total amount of } \\
\text { dry matter, \% }\end{array}$ & 12.25 & 12.42 & 12.68 \\
\hline \multicolumn{4}{|c|}{ Mass fraction, $\%$ : } \\
\hline NFMS & 8.52 & 8.89 & 8.92 \\
\hline fat & 4.18 & 4.25 & 4.24 \\
\hline lactose & 4.35 & 4.47 & 4.52 \\
\hline protein & 3.22 & 3.34 & 3.41 \\
\hline casein & 2.73 & 3.00 & 3.02 \\
\hline
\end{tabular}

Analyzing milk appearance and consistency in all experimental groups of cows, it should be noted that all samples were presented with a homogeneous liquid without sediment, in taste and smell - clean, without foreign tastes and odors, in color - white, with a slightly yellow tint.

Due to the high production culture and balanced diet of cows in the farm, the indicators of active and titrated acidity in the milk of all the studied animals did not undergo significant changes and corresponded to normal values $-16^{\circ} \mathrm{T}$, which is typical for fresh milk.

In TR TS 33/2013, the content of NFMS is regulated, reflecting the quality and full value of the milk. According to the results of our studies, the milk of all groups contained more than $8.5 \%$ NFMS, which corresponds to EXTRA milk grade.

In addition to the main indicators (fat, protein) of nutritional values of milk, casein plays an important role in the production of dairy products. Casein is the main component that affects the structural and mechanical properties of the rennet clot. Stating the data obtained, it should be noted that the use of protein concentrate in the diet increases the casein content in the milk of the experimental groups. In this way, when including $1.0 \mathrm{~kg}$ of protein concentrate, the amount of casein increased by $0.27 \%$, and in the third group -0.29 $\%$, which was higher in relation to the control group. Thus, the milk of the animals of the 2nd and 3rd experimental groups was distinguished by more pronounced cheese-making qualities.

Having estimated the total content of milk carbohydrates - lactose, it should be noted that the inclusion of protein concentrate "Agro-Matic" in the amount of $1.0 \mathrm{~kg}$ and $1.5 \mathrm{~kg}$, does not have a negative effect on its concentration in milk. With an increase in the introduction of protein concentrate, there is a tendency to increase lactose with milk. In this regard, in order to estimate the total energy value of milk, a calculation was made according to Tyrrell H.F. \& J.T. Reid (1965) [1].

According to the energy value in comparison with the milk of cows from the experimental groups, it should be noted that in control group cows, that received only vegetable feed as a source of protein, it was the lowest, and when the maximum level of protein concentrate was included, the highest and amounted to $3,179.51 \mathrm{~kJ} / \mathrm{kg}$ against $3,080.31 \mathrm{~kJ} / \mathrm{kg}$ in the control group.

The efficiency of milk production by agricultural enterprises depends not only on the level of milk productivity, but also on the health of animals and reproduction indicators. 
The results of protein concentrate application on the reproductive performance of cows are shown in Figure 1.

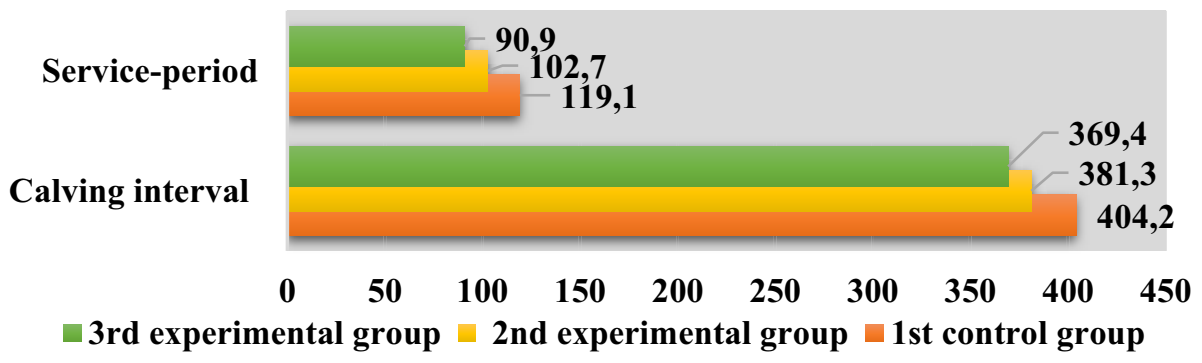

Fig. 1. Reproduction indicators in experimental cows $(n=15)$, day.

The calving interval in the control group when using traditional protein feeds of the main diet in the animals of the control group was the greatest. Thus, the cows that received protein concentrate as part of the diets compared to the animals from the control group, the calving interval was lower than the level of the $2^{\text {nd }}$ experimental group - by 22.9 days, and in the $3^{\text {rd }}$ - by 34.8 days, respectively.

The insemination index is characterized by the number of doses of semen from breeding bulls spent on efficient insemination. In this way, the use of $1.0-1.5 \mathrm{~kg}$ of protein concentrate in the diet contributed to a decrease in the experimental groups to 1.8-2.2 units, respectively. The use of protein concentrate "Agro-Matic" in the amount of 1.0-1.5 $\mathrm{kg} / \mathrm{head} /$ day increases the reproduction rates. Nevertheless, when the largest amount of protein concentrate was added to the composition, the service-period (the period from calving to fruitful insemination) was 90.9 days, which was 28.2 days lower than the control.

The analysis of taxonomically informative marker genes makes it possible to identify and quantify uncultivated microorganisms and is widely used to identify microorganisms associated with such differences as the reaction to the diet, methane formation, feed efficiency, and milk composition $[3,10,13]$.

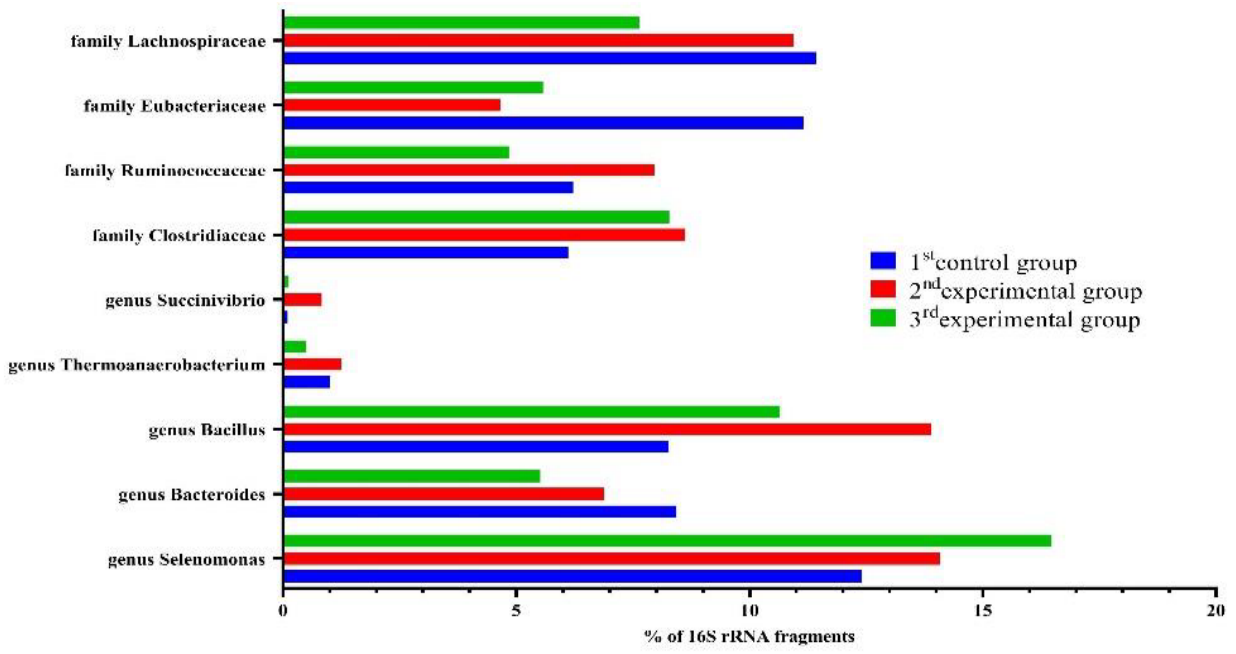

Fig. 2. Structure and species composition of normal flora in the rumen in cows, \%.

Ruminants have a basic microbiome consisting of phylum Firmicutes and Bacteroides, present in all animals in different geographical ranges, but with greater variation among 
individual animals. The phylum Bacteroides and Firmicutes can reach $80 \%$ of the bacterial community. Firmicutes use starch, cellulose, xylan, hemicellulose, galactomannan as an energy source.

In the experimental groups of cows, an increase in the content of microorganisms Bacteroids by $1.5 \%$ and $2.9 \%$, respectively, was observed (Fig. 2). The main function of these microorganisms is protein digestion, and the reduction of this group of microorganisms in relation to the control is probably due to an increase in the protein level in these groups, which is the main substrate for their growth.

During the experiment, the experimental groups showed an increase of $1.7 \%$ and $4.1 \%$ in the content of bacteria of the Selenomonad group cleaving the urea. The most studied inhabitants of the cow rumen with different mechanisms of fiber digestion and involved in the depolarization of the cell wall of plants are the phylums of microorganisms: Clostridium, Firmicutes, Ruminococcus, Butyvibrio.

Cellulosolytic fermentation provides cows with energy and ensures the digestibility of nutrients from difficult-to-digest sources. All cows had no deviations from the norm in the content of bacteria - cellulosolytic, amylolytic, transit and pathogenic, which indicates a balanced of animal's diets.

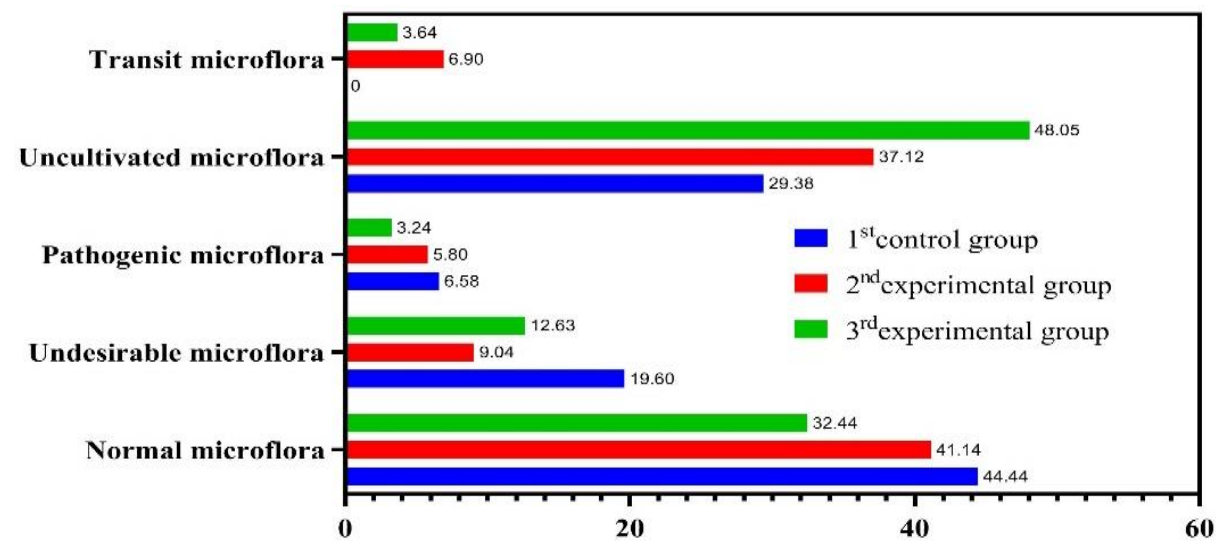

Fig. 3. Structure of microflora in the rumen of lactating cows, $\%$.

The introduction of the protein concentrate "Agro-Matic" into the diet affected the number of cellulolytic microorganisms, as well as the microbiota with antimicrobial activity, such as Bifidobacterium and Bacilli. The total concentration of cellulolytic bacteria in the experimental groups was higher than normal. At the same time, in animals of the 3rd group, their number decreased in comparison with the 2nd group and the control.

The inclusion of $1.0 \mathrm{~kg}$ of protein concentrate in the diet increased the number of cellulolytic bacteria of the Lachnospira family, Ruminococci, clostridium, thermo enterobacteria, bacilli in the rumen content of cows and were within the normal range. Nevertheless, the level of clostridium, Thermoanaerobacteria and Ruminococci in the animals of the $2^{\text {nd }}$ experimental group was higher than the level of the control group by $2.5 \%, 0.3$ and $1.8 \%$, respectively.

Comprehensive studies conducted in the APC "Plemzavod "Maysky " on lactating cows, allow to draw the following conclusions:

1. The use of protein concentrate of both $1.0 \mathrm{~kg}$ and $1.5 \mathrm{~kg} / \mathrm{head} /$ day contributed to improving the quality and increasing the yield of dry matter of cow's milk by $0.17-0.43 \%$.

2. The use of protein concentrate in the amount of $1.0-1.5 \mathrm{~kg}$ as part of the diet had a favorable effect on the reproduction indicators of cows. The duration of the service period 
and the number of spent semen doses during insemination of cows decreased in animals receiving the protein concentrate.

3. During the days in milk in cows, with the use of protein concentrate it was observed that increase the content of Selenomonas by $1.7 \%$ and $4.1 \%$, which cleave the urea, indicates a more efficient use of nitrogen in the diet.

\section{Acknowledgements}

The material presented in the article was prepared with the financial support of "AgroMatic" LLC and the "Russian State Agrarian University - Moscow Timiryazev Agricultural Academy" (Project 1.2.1).

\section{References}

1. B.D. Duval, M. Aguerre, M. Wattiaux Peter A. Vadas, J.M. Powell, Water Air Soil Pollut, 227, 329 (2016) https://doi.org/10.1007/s11270-016-2997-6

2. G.N. Zabegalova, I.A. Kasatkina, A.N. Serkova, E.V. Sysoyeva. Impact of the Tirsana BSC energy supplement on the productivity of Ayrshire cows, IOP Conf. Series: Earth and Environmental Science, 624, $012108 \quad$ (2021) doi: 10.1088/1755$1315 / 624 / 1 / 012108$

3. N.P. Buryakov, G.Yu. Laptev, L.A. Ilina, M.A. Buryakova, A.S. Zaikina, I.A. Kasatkina, D.E. Aleshin, International Transaction Journal of Engineering, Management, \& Applied Sciences \& Technologies, 11(14), 11A14A, 1-14, (2020) doi: 10.14456/itjemast.2020.268.

4. A.E. Schriefer, P.F. Cliften, M.C Hibberd, C. Sawyer, V. Brown-Kennerly, L. Burcea, E. Klotz, S.D. Crosby, J.I. Gordon, R.D. Head, J. Microbiological Methods, 154, 6-13 (2018) doi: 10.1016/j.mimet.2018.09.019

5. M. Barbizan, E.E.L. Valente, M.L. Damasceno, S.A. Lopes, E. de S. Tanaka, C.P. Barros, B.V.R. Melo, Livestock Science, 241, $104211 \quad$ (2020) doi: 10.1016/j.livsci.2020.104211

6. M.A. Brooks, R.M. Harvey, N.F. Johnson, M.S. Kerley, Journal of Animal Science, 90 (13), 4985-4994, (2012) doi: 10.2527/jas.2011-4107

7. C.W. Choi, K.H. Kim, S.S. Chang, N.J. Choi, Asian-Australas Journal of Animal Science, 25(9),1269-75, (2012) doi: 10.5713/ajas.2012.12318

8. L.A. Morozova, I.N. Mikolaychik, V.A. Morozov, O.G. Loretts, O.P. Neverova. Research Research Journal of Pharmaceutical, Biological and Chemical Sciences, 9(5), 1792-1984 (2018)

9. M. Williams, C.P. Murphy, R.D. Sleator, S.C. Ring, D.P. Berry, Journal of Dairy Science, 104(1), 561-574 (2021) doi: 10.3168/jds.2020-18941

10. M. Clauss, J. Hummel, Revista Brasileira de Zootecnia, 46(7), 606-613 (2017) doi:10.1590/s1806-92902017000700008

11. C.D. Dechow, G.W. Rogers, J.B. Cooper, M.I. Phelps, A.L. Mosholder, Journal of Dairy Science, 90, 3542-3549 (2007) doi: https://doi.org/10.3168/jds.2006-889

12. Ruba A.I. Mohamed, A.S. Chaudhry, Nutrition Research Reviews, 21(1), 68-81 (2008) doi: $10.1017 / \mathrm{S} 0954422408960674$

13. H. Lapierre, R. Martineau, M.D. Hanigan, H.J. van Lingen, E. Kebreab, J.W. Spek, D.R. Ouellet, Animal, 14(S1), 87-102 (2020) doi: 10.1017/S1751731119003173 
14. A.R. Yazdani, Indian Journal of Animal Science, 81(11),1161-1164 (2011)

15. V. Kosolapov, B. Sharifyanov, K. Ishmuratov, V. Kosolapova, E. Salikhov, The use of silos from legume-cereal grass mixtures and energy feed additives in the feeding rations of new-bodied first-calf cows, IOP Conference Series: Earth and Environmental Science, 663(1), 012013 (2021) doi: https://doi.org/10.1088/1755$1315 / 663 / 1 / 012013$ 